\title{
Religion and Education in a Secular Age: A Comparative Perspective
}

Religion et éducation dans un âge séculaire: une perspective comparatiste 世俗時代的宗教與教育: 比較的視角

\section{Peter van der Veer}

\section{(2) OpenEdition}

\section{Journals}

Electronic version

URL: http://journals.openedition.org/extremeorient/198

DOI: 10.4000/extremeorient.198

ISSN: 2108-7105

Publisher

Presses universitaires de Vincennes

Printed version

Date of publication: 1 November 2011

Number of pages: $235-245$

ISBN: 978-2-84292-334-1

ISSN: 0754-5010

\section{Electronic reference}

Peter van der Veer, «Religion and Education in a Secular Age: A Comparative Perspective », Extrême-

Orient Extrême-Occident [Online], 33 | 2011, Online since 01 November 2014, connection on 10

December 2020. URL : http://journals.openedition.org/extremeorient/198 ; DOI : https://doi.org/

10.4000/extremeorient. 198 


\title{
Religion and Education in a Secular Age: A Comparative Perspective
}

\author{
Peter van der Veer
}

The modern nation-state demands its subjects to be disciplined and educated in a national curriculum. That curriculum contains the basic elements of modern science, required for educating an adequate workforce, but also basic elements of national culture, such as language and history. Religion can be regarded as part of national culture, but in secularist states students are taught to reject that part of culture, see it as a historical aberration and become atheist. I define here secularism as a project to remove religion from public life and, if possible even from public consciousness, that can be in Communist societies, such as China. It bears family resemblance with secularist projects in non-Communist societies, such as France, but it is much more extreme. Secularism as an ideology offers a teleology of religious decline and can function as a self-fulfilling prophecy. It is important to examine the role of intellectuals in furthering this understanding of history but also their relation to sources of power: state apparatuses and social movements. Secularism is a forceful ideology when carried by political movements that capture both the imagination and the means to mobilize social energies. At the same time it is important to attend to the utopian and, indeed, religious elements in secularist projects in order to understand why many of these movements seem to tap into traditional and modern sources of witchcraft, millenarianism, and charisma. Moreover, we need to consider the secular and the religious as mutually constitutive, so that also what is religious is shaped by secularism.

As long as religion has not been successfully removed from society (and in reality it never is which constantly fuels the secularist project) it needs to be regulated. As a project secularism has its ends (atheist society), its means (education), its resources (taxation) but, importantly, also its obstacles and limitations. It is sometimes strongly supported by state officials and political leaders and sometimes it is deemed of less importance or even discarded. Its description therefore requires historical and spatial specificity. In Shanghai today 
(but not in the 1920s) it is hard to find public manifestations of religion (although one can find them), but in Xiamen, for instance, it is not difficult at all. Since intellectuals are central to education and the understanding of national culture and, in many cases like China, are civil servants connected to the state their debates require special attention, as is shown, for instance, in the membership of the French Stasi Commission that advised the government on its relation to Islam (among others Mohammed Arkoun, Régis Debray, Alain Touraine, Gilles Kepel, Jean Baubérot, well-known French intellectuals and scholars).

Secularism as a project is different from secularization as a process. In Western Europe (but not in the USA) we see a process of "unchurching," in which there is a decline of church membership and church attendance. In such secularized societies, like the Netherlands or Germany, one may still have schools that are governed by a school board that belongs to a religious community, but financially supported by tax money and under the supervision of state inspection, while the curriculum is hardly different from state schools. In Europe today religion is mostly taught in as a secular subject of interest in developing multiculturalism. This again is different from India (a society that is in many ways comparable to China) where religious communities are teaching their own religion in state-sponsored schools, but within the framework of a national curriculum. The location of religion in educating national subjects is, obviously, a function of the location of religion in the imagination of the nation. If religious education has to take place entirely outside of the state-supported school system religious groups need to find other sites for educating its members in the basic tenets of the faith and the methods of religious communication.

\section{Religious Education}

Education is central to religion. To be able to send, receive, and interpret the religious message one needs to be educated. Despite the Deist claim that religion is natural, it is in fact culturally acquired. One could perhaps compare learning a religion with learning a language, and indeed ritual communication has often been studied as a form of language. Many religions have ritual manuals about what to do when and for what purpose and this practical knowledge may be more important than the content of what people believe, or their "inner states," although some religions, especially Protestantism, do put a lot of emphasis on interiority. This is not to say that the concept of "belief" has no significance in Chinese religions. Buddhism does have a set of dogmas and does emphasize liberating insight or belief as an important step towards the end of suffering. The education in sacred truth, in sacred rituals, in correct behavior is an indispensable element of religions. If we think of the ways in which we are socialized to 
understand symbols (religious and non-religious) and their relation to practice it is clear that we have to study not only religions but also how religious symbols become authoritative in relation to other representations and discourses. ${ }^{1}$ For example, if one becomes a Buddhist in a Communist country Buddhist symbols are discursively constructed and understood in relation to the dominant (or state-supported) discourse of Communism.

Where does this education take place? People are, first of all, educated within their families and one should never forget how important early socialization within the family is for acquiring particular habits, patterns of thought, both linguistic and extra-linguistic. It is also in the family that religious dispositions are acquired. This kind of informal education has been dominant everywhere till the 19th century and still prevails in many parts of the world. Given the gendered division of labor in many societies fathers and mothers have often a different role in religious education. In Brahman families in India it is often the mother that imparts a devotional sensibility, while the father often educates his sons in ritual and theological knowledge.

A special case is the "home schooling" movement in the USA that has brought formal education into the family in one of the technologically most advanced societies in the world. The rise of formal education outside the family has been a 20th-century phenomenon and in many places only a late20th-century phenomenon. In societies in which one does not have enough schools for the population informal education in the family is still the only thing available. Where one does have a developed school system it remains important, as Bourdieu points out, that there is a synergy between familial and school education for acquiring specific knowledge, tastes, and skills for the reproduction of class. ${ }^{2}$

One way of estimating the spread of education in a society is looking at literacy rates. Even in a fast developing society as India literacy is not universal and the literacy rate is around 74 percent in 2011 and shows great gender disparity ( 82 percent for men, 65 percent for women). This is different in China where literacy is above 90 percent now, but for most of its history China has had low literacy rates like everywhere else. Illiterate parents cannot teach children to be literate, so that the spread of formal education is essential in acquiring literacy skills. Such skills have also their effects on religion, since reading and comprehending religious texts transform the ways in which religious dispositions are formed. It can, for instance, be argued that the translation of the Bible in the vernacular and its spread by means of the new printing technology made

1. Asad, Genealogies of Religion, p. 31-32.

2. Bourdieu, The State Nobility. 
Protestantism attractive. It is therefore important to realize that large parts of the population of China were illiterate till relatively recently and that this fact is relevant to understand the nature of religion in China in the past and its change in the present.

Outside of the family it is the temple and the monastery that are throughout history sites of education. Again, it is relatively recent that they have been rivaled or overtaken by state sponsored schools. It was only in the late 19th century that in Europe the old universities of Oxford and Cambridge were loosening their ties with the state church. Still, many of the arrangements in these universities (and elsewhere in Europe) recall the religious nature of higher learning. This was also true for China, obviously. To be educated for major administrative positions one needed to learn interpretations of the classical canon that were tied up with an imperial ritual system and a Confucian cosmology. The centralization of the examination system has been one of the major features of the development of the bureaucracy in China and looked at with admiration from outside of China. It does not seem to be correct to see this as a secular system, since it partly promoted what one could call a Confucian mind-set, a kind of moral and political theory, as well as a ritual complex that legitimated the sacred nature of the imperial system. ${ }^{3}$

\section{Secular Rationality}

This raises the question of the rise of secularism. The reformers at the end of the Qing period were in many respects not very different from reformers in India or other parts of Asia. Their main concern was to provide a modern curriculum that would enable their societies to "catch up" with the fast modernization of Europe. Very important in the 19th century is the growing centrality of scientific knowledge in which empirical observations are combined with mathematical models. It is not anymore the case that knowledge is produced within a religious system or with reference to a classical canon. It is produced outside of that system and in principle indifferent to it. The main element in that indifference is that religious claims for fundamental knowledge about nature become increasingly untenable and cannot be allowed to obstruct scientific inquiry. The secular (not secularist) demand for better education to enable progress does not have to do away with religion and in many cases in Europe, the USA, or India it does not. In principle religious schools can accommodate rational inquiry and scientific knowledge. In fact, Christian schools in Europe and in the colonies in the late 19th century often prided themselves on the excellence of their

3. Elman \& Woodside (eds.), Education and Society in Late Imperial China. 
secular curriculum. Indeed, major schools and institutions of higher education in India and China have their origin in Christian missions. After the polemics surrounding Darwin's discoveries a split occurred in Protestant churches between those who accepted the findings of modern science and those who rejected it. In the Catholic Church the authority of the Pope determined the relation between science and religion, but gradually Catholicism has also embraced the notion that it is completely in tune with modern science which effectively means that it has abandoned its authority in this field. ${ }^{4}$

In the 19th century a substantial number of Protestant institutions began to develop the stance that modern science was compatible with Christianity, creating a growing split between liberal ("progressive") Protestantism and forms of traditional Protestantism (Evangelicalism, Pentecostalism, and others) that rejected especially Darwinism. In the missionary field this liberal perspective on modern Christianity was accompanied by the claim that other religions were "backward" and an obstacle to progress. From a 19th-century evolutionary perspective Christianity belonged to an "advanced" society, while religions like Islam, Hinduism, or Daoism could be portrayed as steeped in ignorance. This attack on the backwardness of native religions led in turn to native apologetics that stressed the scientific nature of the religions in question and often claimed their scientific superiority. In that way religion's relation to science became a major criterion for its suitability to modern society.

If religious education cannot anymore impart knowledge about nature it can still be important in teaching moral conduct. An important distinction that is made in the 19th century and is prevalent till today is that between magic as pseudo-science and religion as a source of positive morality. We find a classic statement of this opposition in Edward Tylor's work, but more influential has been Weber's theory of rationalization and disenchantment. Weber does not argue that there is a process of decline of religion, but rather that religion purifies itself from magical elements and reaches (first of all in Protestantism) a higher stage of morality and rationality that is conducive to economic and societal progress. While Weber emphasizes the role of religious groups, priests and charismatic innovators in this process of rationalization, Marx sees such groups as simple tools of the ruling class and the religious morality of capitalism as another form of magic, namely commodity fetishism that has to be overcome to allow for the liberation of the people. Both strands of sociological analysis, based in Enlightenment thought, have had great influence on the issue of religion and education in China. Popular religion or superstition (mixin) were forms of magic and people had to be educated to discard these wrong beliefs. Monastic

4. Fassin, "The Geopolitics of Vatican Theology". 
religions, such as Buddhism and Daoism, were seen as too much connected to popular magic to be able to perform this task of educating the masses. Reformers like Taixu in Buddhism responded to that by proposing substantial reforms in Buddhism to make it a modern, national religion with transnational connections.

\section{National Religion}

The move to make religion into the source of national morality, conducive to progress, requires the nationalization of religion. ${ }^{5}$ This development we find both in Europe and in Asia in the second half of the 19th century. Religion becomes one of the fields of disciplinary practice in which the modern self is produced. It is seen as not only important in the production of the modern subject but also in the production of the modern public. Consequently, religion is important not only in the shaping of religious conscience and civilized conduct, but also in the creation of the public sphere. In Britain and in India missionary movements have been central to the development of a public sphere in which not only modern Christianity, but also religious reform in other religions as well as anti-colonialism was shaped. Although Christian conversion had some success in the colonized world and in India and China it remained marginal in terms of numbers, the real impact has been on indigenous religions. In India a number of Hindu and Muslim reform movements built their own schools and universities with a modern curriculum and a nationalist agenda. In China this seems to have been less the case, although attempts were made to introduce a Confucian nationalism in the schools. However, these were state schools and not schools supported by religious movements. In his paper for this issue Liu Xun shows that the Nanyang Daoist monastery did start modern schools and vocational training programs. This then was an initiative taken by Daoist clergy with the support of the laity and thus dependent on donations in the form of temple lands. By being dependent on landholdings they were easy targets for secularist attacks. Lay movements are much more difficult to target, since they spring from the common people that make up the nation. According to Angela Leung the Yangtze Delta had already a substantial number of charitable schools in the 17 th and 18 th centuries. ${ }^{6}$ In her analysis these community schools for the poor were important instruments in a cultural war against an emerging popular culture. Here, again, is the remarkable emphasis on disciplining rather than

5. Van der Veer, "L'État moral: religion, nation et Empire dans la Grande-Bretagne Victorienne et l'Inde britannique."

6. Leung, "Elementary Education in the Lower Yangtze Region in the Seventeenth and Eighteenth Centuries." 
educating the masses that continues till the present day. It shows how much earlier elite misgivings about popular religion preceded the modernist antireligion campaigns in the 19 th and 20 th centuries.

The concerted attacks on religious institutions and the professed emphasis on building secular schools is something we know from Communist rule everywhere. In that sense Communism is a true heir of the Jacobinism of the French revolution. However, the Chinese case is different from, say, East-European cases in that these attacks started long before the victory of Communism. As many scholars have pointed out attacks on religious institutions under the rubric of removing obstacles to progress began already in the last decades of the Qing dynasty. Various forms of nationalism try to destroy popular religion which includes arbitrarily from time to time forms of formal, monastic Daoist and Buddhist religion. This is completely different from the Indian case in which religion is the basis of anti-colonial nationalism. It is Christian colonialism that is seen by many Indian nationalists as threatening the nation despite the fact that the colonial government takes pains in showing religious neutrality and in many ways distances itself from Christian missions. In India therefore the educational field is filled with religious initiatives of a wide variety of movements and communities who all want to stem the expansion of Christianity and enhance the upward mobility of their group or community. In China it is the indigenous state itself, however pressurized by imperial forces, that takes on the competition with the West and turns against the indigenous religion as cause of the nation's backwardness. In the last analysis it is the nature of state-society relations that determines the location of religion in it. In India in the early 19th century the East India Company was giving patronage to temples and festivals, following the pattern of Hindu and Muslim kingdoms. It is only under great pressure from Christian evangelical groups in Britain that the company was forced to withdraw its support of "idolatrous, heathen" practices and develop a policy of religious neutrality. However, this was only a withdrawal of sorts since the British then became very active in setting up systems and committees to manage religious endowments. These committees, in turn, became important arenas for organizing the public sphere, for both Hindus and Muslims. ${ }^{7}$

\section{The Language of Instruction and the Instruction of Language}

This is not to deny that all colonial parties - missionaries, traders, and administrators - understood civil society to be based on Christian civilization and thus supported all efforts to use education to reform Indian society. To advocate

7. Van der Veer, Imperial Encounters. 
the spread of English to the higher classes as against supporting the "oriental languages" the administrator Thomas Babington Macaulay (himself a son of a missionary) wrote a famous Minute on India Education (1835) in which the education in English literature was recommended to spread civilization, from which I want to cite the following telling passage:

I have no knowledge of either Sanscrit or Arabic. -But I have done what I could to form a correct estimate of their value. I have read translations of the most celebrated Arabic and Sanscrit works. I have conversed both here and at home with men distinguished by their proficiency in the Eastern tongues. I am quite ready to take the Oriental learning at the valuation of the Orientalists themselves. I have never found one among them who could deny that a single shelf of a good European library was worth the whole native literature of India and Arabia. The intrinsic superiority of the Western literature is, indeed, fully admitted by those members of the Committee who support the Oriental plan of education.

It is both missionary and secular literature that is put to the service of educating the natives. This point is of more general significance given the importance of literature (prose and poetry) to educate elites about themselves (emotions, intentions, meaning of life) in modern societies, in which sacred texts have lost their monopoly of moral education. It is modern English education in literature and science that does the civilizing work, while Indian classical learning, rooted in Hindu or Muslim civilization, is discarded or marginalized.

One may suggest that the opposition between secular and religious needs to be redrawn in India under colonial conditions between modern secular Christian on the one hand and traditional religious Hindu, Muslim, Buddhist, Taoist on the other. Macaulay's speech as a Member of the India Council highlights another element that is of high importance in Indian education:

We must at present do our best to form a class who may be interpreters between us and the millions whom we govern, -a class of persons Indian in blood and colour, but English in tastes, in opinions, in morals and in intellect.

India, obviously, was impossible to govern from small and far-away England and was thus to be ruled by native servants of the Empire. Colonial policy made English into an Indian language which it is today, but simultaneously it made it into the language of the ruling class which it continues to be. In India, therefore, we find a "split" public sphere with English on the one hand and the various vernacular languages on the other.

Written Mandarin, largely based on Northern dialects of Chinese, has been a great unifier in Chinese dynastic history for a very long time and this has been reinforced by the Imperial examinations. There has therefore never been a doubt that it would continue to be the language of instruction in Republican China. It 
has further undergone a major standardization and simplification in the PRC. The distinction that one makes in India between English and vernaculars is made in China between "the common language" (putonghua) and the various dialects and languages that are spoken in China (and are in a number of cases mutually unintelligible). This produces a linguistic situation that is more similar to Europe where the state language (dependent on centralized education) marginalizes local and regional languages than to India where the colonial situation produced a split public sphere and an education system that employed besides English a number of vernaculars as languages for instruction. Given the dominance of Mandarin Chinese in China there is also much less scope for regional demands to be instructed in regional languages instead of Mandarin. This in turn makes separatism on the basis of language less viable than in India. In fact, in China it is not ethno-linguistic mobilization, but the state in its EthnoNational Identification Project of the 1950-70s that first classifies 56 officially recognized ethnicities (partly based on linguistic criteria) and then develops guidelines for the strengthening of minority education, including language. This ethnicity policy has come under intense pressure after the reforms of 1978 from arguments that blame language for the "backwardness" of minorities which has led to the new National Common Language Law of the PRC, passed in 2000, which requires knowledge of Chinese to qualify for citizenship. ${ }^{8}$ The effects of mass migration to the urban centers of China on linguistic diversity can similarly be expected to be substantial.

In India linguistic nationalism per se has not led to the break-up of the nationstate, but a linguistic configuration has developed in which large numbers of people speak three languages: English, Hindi (a widespread national language that is also used in Bollywood movies) and the regional language. In combination with religion, however, language became one of the elements in the political mobilization of Hindus and Muslims. Urdu and Hindi are basically the same language, but Urdu uses Perso-Arabic script and a vocabulary largely derived from Arabic and Farsi, while Hindi is written in Sanskritic script and uses a Sanskritic vocabulary. The spoken language (often called Hindustani) was, more or less, a mix between these vocabularies with local and regional influences. From the end of the 19th century language mobilization around Hindi and Urdu, especially focusing on the language of education and administration and thus on the availability of government jobs, were an important part of growing communal antagonism. Despite the fact that Muslims in different parts of India spoke regional languages Urdu became the language of Muslim separatism and the national language of Pakistan. However, in the 1970s East Pakistan with

8. Bilik, "Language, Ethnicity, and Internal Frontiers." 
its Bengali-speaking Muslim population broke off from Pakistan and formed Bangladesh (the country of Bengalis) partly because of linguistic discrimination.

In China, however, language is not in that way intimately tied to religious communities, except for Tibetan Buddhists and Uyghur Muslims who indeed on a variety of religious, cultural, and linguistic grounds demand a separate nation/state. The Hui minority in China lives dispersed over the country and speaks mutually unintelligible dialects and languages very much like Muslims in India who speak Tamil, Malayalam, or Bengali, the languages of the regions in which they live. However, the Hui do not have a numerical presence in China and a widespread "Muslim language" like Urdu that could provide for strong ethnic-religious mobilization. Arabic, the language of the Quran, provides access to religious texts in madrassa education but is in India and in China not the language of communication among Muslims. Similarly, Buddhists and Taoists learn forms of language that give them access to the sacred canon, but these are languages of religious education rather than communication.

In China today there is a disjuncture between the widespread availability of temples, monasteries, sacred places as well as the ubiquitous availability of numerological speculation and geomancy on the one hand and the removal of religion from education on the other. How then do people learn about religious ideas and behavior outside the family? When it is more or less allowed to perform religion how does one know what is correct and what is not in the absence of religious education? It is striking that in the emergence and rise of the Falungong out of the plethora of Qigong movements in the 1990s it is not the internal religious debate about correct beliefs and practices that determine its fate, but the decision by the state that it is politically dangerous. By banning religion from education, but not from public life and consciousness the state is effectively leaving this social space open for religious imagination. This imagination is fuelled by a wide range of image producers, most prominently television and film. This may not make religion into a viable ingredient of an emerging public sphere, as is the case in Taiwan according to Richard Madsen, but it does produce a highly creative arena of exploration. ${ }^{9}$

9. Madsen, Democracy's Dharma. 
Religion and Education in a Secular Age: A Comparative Perspective

\section{BibLIOGRAPHY}

AsAd Talal, Genealogies of Religion, Baltimore, Johns Hopkins University, 1993.

BILIK Naran, "Language, Ethnicity, and Internal Frontiers: Schooling Civil Society among China's Minorities," in Veronique BENEI (ed.), Manufacturing Citizenship. Education and Nationalism in Europe, South Asia and China, London, Routledge, 2005, p. 210-235.

Bourdieu Pierre, The State Nobility: Elite Schools in the Field of Power, Oxford, Oxford University Press, 1996.

Elman Benjamin A. \& Woodside Alexander (eds.), Education and Society in Late Imperial China, 1600-1900, Berkeley, University of California Press, 1994.

FAssin Eric, "The Geopolitics of Vatican Theology," Public Culture 19, 2007, p. 233 237.

Leung Angela, "Elementary Education in the Lower Yangtze Region in the Seventeenth and Eighteenth Centuries," in Benjamin A. Elman \& Alexander Woodside (eds.), Education and Society in Late Imperial China, 1600-1900, Berkeley, University of California Press, 1994, p. 381-417.

Madsen Richard, Democracy's Dharma: Religious Renaissance and Political Development in Taiwan, Berkeley, University of California Press, 2007.

VAN DER VEER Peter, « L'État moral: religion, nation et Empire dans la Grande-Bretagne Victorienne et l'Inde britannique », Genèses 26, 1997, p. 77-103.

VAN DER VeER Peter, Imperial Encounters. Nation and Religion in India and Britain, Princeton, Princeton University Press, 2001.

\section{Chinese Character List}

Falungong 法輪功

mixin 迷信

putonghua 普通話

qigong 氣功

Taixu 太虛 
